\title{
Wound healing activity of topical phenytoin in excision wound model of Albino rats
}

\author{
Usha N. S. ${ }^{1}$, Sirisha G. ${ }^{2}$
}

${ }^{1}$ Department of Pharmacology, MVJ Medical College and Research Hospital, Hoskote, Bangalore, India

${ }^{2}$ Department of Pharmacology, Nizam's Institute of Medical sciences, Hyderabad, Telangana, India

Received: 07 October 2016 Accepted: 03 November 2016

*Correspondence to:

Dr. Usha N. S.,

Email: drusha26@gmail.com

Copyright: (C) the author(s), publisher and licensee Medip Academy. This is an openaccess article distributed under the terms of the Creative Commons Attribution NonCommercial License, which permits unrestricted noncommercial use, distribution, and reproduction in any medium, provided the original work is properly cited

\begin{abstract}
Background: Wound healing is a major medical entity. Phenytoin being an anticonvulsant drug has shown promising results in healing chronic wounds. In the present study we have evaluated the effect of topical Phenytoin on excision wound models of albino rats.

Methods: Phenytoin ointment of $1 \%, 5 \%$ and $10 \%$ were used topically on experimental animals. Neomycin used as reference standard. In Excision wound model period of epithelialization, area of wound and hydroxyproline content were evaluated.

Results: Phenytoin $1 \%, 5 \%$ and $10 \%$ have shown significant $(\mathrm{P}<0.001)$ wound healing property compared to control and Neomycin. Phenytoin hastened the wound healing compared to control and neomycin and increased hydroxyproline content of wound. Phenytoin $5 \%$ has better wound healing property compared to $1 \%$ and $10 \%$.

Conclusions: The present study has shown that Phenytoin reduces time for wound healing and improved the quality of healing tissue which provides rationale for use in chronic wound in clinical setting.
\end{abstract}

Keywords: Excision wound, Hydroxyproline, Phenytoin, Wound healing

\section{INTRODUCTION}

Wounds are inescapable events of life. Non-healing and chronic wounds pose significant health care problems in today's medical practice. ${ }^{1}$ The wide spread of other chronic wounds, example: Diabetic wounds, war related missile wounds and venous stasis ulcer, further underscores the need for efficacious wound healing intervention. ${ }^{2}$ Wound is a breech in continuity of tissue. Wound healing has a complex mechanism which holds numerous steps involving coagulation, inflammation, granulation tissue formation, matrix formation, connective tissue remodelling, collagenisation and wound strength acquisition. ${ }^{3}$ Wounds have varying effects on the quality of life of those affected, their families and care givers. Appropriate treatment and wound care accelerates the healing process and prevents infection and chronicity of wound. Different methods and approaches have been used to achieve shorter wound healing times. ${ }^{1}$ The quest for better wound healing agents is perhaps one of the oldest challenges for medical practice. ${ }^{4}$ Currently, much attention and faith are being placed on development of expensive topical molecular factors for enhancement of wound healing. One such agent that has been tried in wound healing is Phenytoin. A common dose related side effect with Phenytoin when taken orally in treatment of epilepsy is gingival hyperplasia which led Shapiro to carry out first clinical study to evaluate the effect of Phenytoin on gingival wounds. ${ }^{4}$ Phenytoin may promote wound healing through multiple mechanisms, including stimulation of fibroblast proliferation, facilitation of collagen deposition, glucocorticoid antagonism and antibacterial activity. This apparent stimulatory effect of Phenytoin on connective tissue suggested an exciting 
possibility for its use in wound healing. Phenytoin is inexpensive,easy to use and readily available. ${ }^{5}$ Previous animal studies have been done for evaluating wound healing effect of topical Phenytoin on Excision and Incision wound models using 1\% Phenytoin and 10\% Phenytoin. ${ }^{1,2,6}$ Only few studies includes detailed histological and biochemical assessment of Phenytoin on wound healing. Hence present study was undertaken to evaluate the effect of topical Phenytoin on excision wound models using three different concentrations of Phenytoin and assessment of biochemical parameter.

\section{METHODS}

\section{Drugs and chemicals}

Phenytoin sodium

Neomycin ointment

Soft paraffin

Liquid paraffin

Diethyl ether

\section{Animals}

A total of 60 healthy $(180-200 \mathrm{~g})$ wistar albino rats of either sex were selected from central animal house. All animals were housed under controlled conditions of temperature $\left(25^{\circ} \pm 2^{\circ} \mathrm{c} \quad 12: 12\right.$ hour dark/light $)$ offered standard pellets. All animals housed individually in polypropylene cages. The study was under taken after obtaining approval of IAEC.

\section{Study design and drug administration}

30 rats were divided randomly into 5 groups. 6 rats in each group for excision wound model and separate set of 30 rats divided into 5 groups, 6 rats in each group for Hydroxyproline estimation (Table 1).

\section{Preparation of ointments}

Control/base: Soft paraffin and liquid paraffin mixed in 10:1 ratio on porcelain tile using spatula to make an ointment base acts as control.

\section{Phenytoin ointment:}

Phenytoin sodium is used in 3 doses $1 \%, 5 \%$ and $10 \%$

Phenytoin $1 \%-99 \mathrm{~g}$ ointment base $+1 \mathrm{~g}$ Phenytoin powder

Phenytoin 5\%-95g ointment base $+5 \mathrm{~g}$ Phenytoin powder

Phenytoin 10\%-90g ointment base $+10 \mathrm{~g}$ Phenytoin powder

Phenytoin powder is mixed evenly with the ointment base without lumps on porcelain tile using spatula.

\section{Wound model}

Under light ether anaesthesia excision wounds were inflicted as described by Morton and Malone. ${ }^{7}$ The anesthetized animals were secured on the operation table. The fur of dorsum of each animal on either side of vertebral column was shaved and ethanol $70 \%$ was applied as an antiseptic for the shaved region before wound creation. The impression was made on dorsal interscapular region on both sides of vertebral column $5 \mathrm{~mm}$ away from ear and $1 \mathrm{~cm}$ away from vertebral column using circular rubber stamp of $25 \mathrm{~mm}$ diameter. A full thickness of excision wound of circular area of $500 \mathrm{~mm}^{2}$ was created. Haemostasis was achieved by blotting the wounds with cotton swab soaked in normal saline. The entire wounds were left open. All surgical procedure was performed under aseptic conditions. The control group animals were treated with Base (liquid paraffin and soft paraffin mixture). Reference standard group was treated with Neomycin $0.5 \%$. Other groups were treated with Phenytoin 1\%, Phenytoin 5\%, and Phenytoin 10\%. All drugs were applied once daily topically till the wounds were completely healed. Wound closure rate was assessed by tracing wound on day 0,4 , $8,12,16$ using transparent paper and marker pen. The wound area was measured using graph paper. The wound traced paper is placed on graph paper and number of 1 $\mathrm{mm}^{2}$ squares was counted of the traced wound. The period of epithelialization was calculated as number of days a required for fall of scab (dead tissue) leaving no raw wound after inflicting excision wound.

\section{Biochemical estimation}

Hydroxyproline content of tissue was estimated as described by woessner ${ }^{8}$. Biopsy specimen was collected from Excision wound on $6^{\text {th }}, 10^{\text {th }}$ and $14^{\text {th }}$ day under light ether anaesthesia without sacrificing animal. Procedure: The biopsy specimen was collected from Excision wound from each group on $6^{\text {th }}, 10^{\text {th }}$ and $14^{\text {th }}$ days. The excised wound tissues were dried in hot air oven at $60^{\circ} \mathrm{C}$. After drying, the dry weight was recorded and the whole tissue was hydrolysed at $130^{\circ} \mathrm{C}$ for 24 hours in $5 \mathrm{ml}$ of $6 \mathrm{~N} \mathrm{HCl}$ and then the hydrolasate was neutralized to $\mathrm{PH} 7.0$ and subjected to $450 \mu \mathrm{l}$ of Chloramine-T Oxidation for 20 min. The reaction was terminated by addition of Perchloric acid $\left(0.4 \mathrm{M} \mathrm{HClO}_{4}\right)$ and colour was developed by addition of $500 \mu \mathrm{l}$ Ehrlich reagent at $60^{\circ} \mathrm{C}$. The intensity of colour developed was measured by spectrophotometer at $557 \mathrm{~nm}$. The amount of hydroxyproline in sample was calculated using a standard curve prepared with pure hydroxyproline. Hydroxyproline content of wound sample was measured in $\mathrm{mg} / \mathrm{gram}$ of dry tissue.

\section{Statistical analysis}

The results were expressed as mean \pm SE. The results were analysed for statistical significance using one-way 
Anova followed by post hoc LSD multiple comparison test using IBM SPSS version 19.

\section{RESULTS}

In excision wound model the area of wound was measured on $4,8,12$ and $16^{\text {th }}$ days after wound infliction. Phenytoin in concentrations of $1 \%(187.53 \pm 4.81)$ and $5 \%$ (177.10 \pm 4.81$)$ (Table 2) showed significant reduction in wound area compared to control (208.53 \pm 4.81$)$. Phenytoin 5\% (177.10 \pm 4.81$)$ wounds showed significant reduction in wound area in comparison to Neomycin (196.57 \pm 4.81$)$. Phenytoin $1 \%(187.53 \pm 4.81)$ and $5 \%$ (177.10 \pm 4.81$)$ group wounds showed significant reduction in wound area compared to Phenytoin 10\% $(214.40 \pm 4.81)$.

Phenytoin 5\% wounds significantly required less days for complete epithelialization when compared with Neomycin, Phenytoin $1 \%$ and $10 \%$. The mean hydroxyproline content (Table 4) of wound samples showed that the animal groups treated with Phenytoin $1 \%$ $(0.69 \pm 0.21), 5 \%(0.90 \pm 0.21)$, and $10 \%(1.38 \pm 0.21)$ had significantly high hydroxyproline content compared to control group $(0.60 \pm 0.21)$.
Table 1: Grouping for excision model $(\mathrm{N}=30)$.

\begin{tabular}{|c|c|c|c|}
\hline $\begin{array}{l}\text { Groups } \\
n=6\end{array}$ & Drug & Status & $\begin{array}{l}\text { Route of } \\
\text { administration }\end{array}$ \\
\hline 1 & Base & Control & \multirow{5}{*}{$\begin{array}{l}\text { Applied } \\
\text { topically on } \\
\text { wound once } \\
\text { daily till wound } \\
\text { heals. }\end{array}$} \\
\hline 2 & Neomycin & $\begin{array}{l}\text { Reference } \\
\text { standard }\end{array}$ & \\
\hline 3 & $\begin{array}{l}\text { Phenytoin } \\
1 \%\end{array}$ & Test & \\
\hline 4 & $\begin{array}{l}\text { Phenytoin } \\
5 \%\end{array}$ & Test & \\
\hline 5 & $\begin{array}{l}\text { Phenytoin } \\
10 \%\end{array}$ & Test & \\
\hline
\end{tabular}

There was no significant mean reduction in area of excision wound by control as well as Phenytoin $10 \%$ by end of $16^{\text {th }}$ day. The mean period of epithelialization (Table 3) was faster with Phenytoin group wounds. Neomycin (18.33 \pm 0.33$)$, Phenytoin $1 \%(17.67 \pm 0.33)$, $5 \%(14.83 \pm 0.40$,$) and 10 \%(17.33 \pm 0.21)$ significantly required less days for complete epithelialization compared to control $(21.0 \pm 0.73)$.

Table 2: Mean area of the excision wound in Sqmm (Mean $\pm \mathrm{SE})$.

\begin{tabular}{|llllll|}
\hline Days & Control & Neomycin & Phenytoin 1\% & Phenytoin5\% & Phenytoin 10\% \\
\hline Day 0 & $492.83 \pm 10.35$ & $479.17 \pm 8.91$ & $484.33 \pm 9.35$ & $474.00 \pm 13.06$ & $475.17 \pm 4.45$ \\
\hline Day 4 & $376.50 \pm 10.54$ & $367.67 \pm 6.91$ & $335.00 \pm 7.45$ & $325.83 \pm 8.91$ & $328.50 \pm 7.77$ \\
\hline Day 8 & $109.33 \pm 3.72$ & $85.83 \pm 10.41$ & $78.67 \pm 1.54$ & $68.67 \pm 3.56$ & $210.33 \pm 13.60$ \\
\hline Day 12 & $44.17 \pm 2.29$ & $38.17 \pm 2.86$ & $33.83 \pm 4.73$ & $17.00 \pm 2.54$ & $53.33 \pm 6.69$ \\
\hline Day 16 & $19.83 \pm 1.38$ & $12.00 \pm 1.57$ & $5.83 \pm 0.95$ & $00.00 \pm 0.00$ & $4.67 \pm 1.26$ \\
\hline Average mean \pm SE & $208.53 \pm 4.81$ & $196.57 \pm 4.81$ & $187.53 \pm 4.81$ & $177.10 \pm 4.81^{\text {a }}$ & $214.40 \pm 4.81^{\text {cd }}$ \\
\hline
\end{tabular}

P value $<0.001$; compared to ${ }^{\text {a }}$ control; ${ }^{b}$ Neomycin; ${ }^{c}$ Phenytoin $1 \% ;{ }^{d}$ Phenytoin $5 \%$; ${ }^{\text {e Phenytoin } 10 \%}$

Table 3: Mean days required for complete epithelialization.

\begin{tabular}{|ll|}
\hline Groups & Mean \pm SE \\
\hline Control & $21.0 \pm 0.73$ \\
\hline Neomycin & $18.33 \pm 0.33^{\mathrm{a}}$ \\
\hline Phenytoin 1\% & $17.67 \pm 0.33^{\mathrm{a}}$ \\
\hline Phenytoin 5\% & $14.83 \pm 0.40^{\mathrm{abc}}$ \\
\hline Phenytoin 10\% & $17.33 \pm 0.21^{\mathrm{ad}}$ \\
\hline
\end{tabular}

$\mathrm{P}$ value $<0.001$; compared to a control; ${ }^{\mathrm{b}}$ Neomycin; ${ }^{\mathrm{c}}$ Phenytoin $1 \%$; ${ }^{\mathrm{d}}$ Phenytoin $5 \%$; ${ }^{\mathrm{e}}$ Phenytoin $10 \%$

The hydroxyproline content of phenytoin $1 \%$ $(0.69 \pm 0.21), 5 \%(0.90 \pm 0.21)$, and $10 \%(1.38 \pm 0.21)$ were significantly more in comparison to neomycin group $(0.46 \pm 0.21)$ with increase in the concentration of Phenytoin there was significant increase in hydroxyproline content.

\section{DISCUSSION}

Wound healing is a complex process restoring damaged cellular and tissue structures. Phenytoin is one of the oldest antiepileptic drugs widely used in the treatment of grandmal and psychomotor epilepsy. Kimball first noticed the gingival hypertrophy in patients treated with Phenytoin. ${ }^{9}$ In the light of this observation; studies on effects of Phenytoin on wound healing were undertaken. Shaprio first conducted clinical studies in periodontal patients with surgical wounds. ${ }^{10} \mathrm{He}$ observed that patients pre-treated with oral Phenytoin had less inflammation and pain. Later Phenytoin was proved to be effective in acute and chronic lesions of various etiologies such as decubitus ulcers, leprosy ulcers, diabetic ulcers, traumatic wounds, burns and epidermolysis bullosa. Phenytoin appears to be safe, effective, easy to use and inexpensive treatment modality for wound healing. The present study was designed to study the effect of topical Phenytoin in 
three graded concentrations $(1 \%, 5 \%, 10 \%)$ in excision wound models. Clinical studies done by Modaghegh et al and Muthukumarswamy et al indicate that Phenytoin decrease the bacterial load of wounds. ${ }^{11,12}$

Table 4: Mean hydroxyproline content of wound in $\mathrm{mg} / \mathrm{gm}(\mathrm{Mean} \pm \mathrm{SE})$.

\begin{tabular}{|llllll|}
\hline Days & Control & Neomycin & Phenytoin 1\% & Phenytoin5\% & Phenytoin 10\% \\
\hline $6^{\text {th }}$ Day & $0.38 \pm 0.01$ & $0.29 \pm 0.04$ & $0.45 \pm 0.02$ & $0.63 \pm 0.12$ & $0.92 \pm 0.02$ \\
\hline $10^{\text {th }}$ Day & $0.62 \pm 0.04$ & $0.53 \pm 0.05$ & $0.71 \pm 0.04$ & $0.95 \pm 0.10$ & $1.42 \pm 0.04$ \\
\hline $14^{\text {th }}$ Day & $0.81 \pm 0.02$ & $0.58 \pm 0.13$ & $0.92 \pm 0.09$ & $1.12 \pm 0.07$ & $1.78 \pm 0.02$ \\
\hline $\begin{array}{l}\text { Average } \\
\text { Mean } \pm \text { SE }\end{array}$ & $0.60 \pm 0.21$ & $0.46 \pm 0.21^{\mathrm{a}}$ & $0.69 \pm 0.21^{\mathrm{b}}$ & $0.90 \pm 0.21^{\mathrm{abc}}$ & $1.38 \pm 0.21^{\text {abcd }}$ \\
\hline
\end{tabular}

$\mathrm{P}$ value $<0.001$; compared to ${ }^{\mathrm{a}}$ control; ${ }^{\mathrm{b}}$ Neomycin; ${ }^{\mathrm{c}}$ Phenytoin $1 \% ;{ }^{\mathrm{d}}$ Phenytoin $5 \% ;{ }^{\mathrm{e}}$ Phenytoin $10 \%$

\begin{tabular}{|c|c|c|c|c|c|}
\hline GROUP & DAY 0 & DAY 4 & DAY 8 & DAY 12 & DAY 16 \\
\hline Control & & & & & \\
\hline Neomycin & & & & & \\
\hline $\begin{array}{l}\text { Phenytoin } \\
1 \%\end{array}$ & & & & & \\
\hline $\begin{array}{l}\text { Phenytoin } \\
5 \%\end{array}$ & & & & 10 & \\
\hline $\begin{array}{l}\text { Phenytoin } \\
10 \%\end{array}$ & & & & & \\
\hline
\end{tabular}

\section{Figure 1: Comparison of Area of Excision wounds on} different days.

Modaghegh et al reported that topical Phenytoin eliminates staphylococcus aureus, E.coli, Klebsiella and pseudomonas from wounds within 7-9 days. ${ }^{11}$ In this regard this feature seems to be advantageous in clinically chronic wounds especially in dirty or infected ones. In our study the wounds were clean as excision was done under sterile conditions. Neomycin $0.5 \%$ concentration was used in the study as reference standard.

Moy et al also determined that the effects of Phenytoin on human skin fibroblasts are dependent on concentration and duration. ${ }^{13}$ They observed that the lower concentrations $(5 \mathrm{mg} / \mathrm{L})$ and shorter incubation time (3 hours) increased proliferation significantly; however, higher concentrations $(25 \mathrm{mg} / \mathrm{L})$ and longer incubation time ( $\geq 25$ hours) decreased fibroblast proliferation. So, low concentration of Phenytoin 1\%, intermediate concentration of Phenytoin 5\% and high dose of Phenytoin $10 \%$ were taken for the present study. The area of wound was measured on $4,8,12$ and $16^{\text {th }}$ days after wound infliction. Phenytoin 5\% showed significant reduction in area of wound compared to Neomycin.

Phenytoin $1 \%$ and $5 \%$ group wounds showed significant reduction in wound area compared to Phenytoin $10 \%$ by end of $16^{\text {th }}$ day, because higher concentration of Phenytoin in $10 \%$ lead to formation of hypertrophic granulation tissue as a side effect, which is also noticed by Pendse et al and Muthukumarswamy et al. ${ }^{12,14}$ The hypertrophic granulation tissue covers the wound entirely making the area appear larger while measuring the wound surface. The mean period of epithelialization (Table 4) was faster with Phenytoin group wounds. Phenytoin 5\% wounds significantly required less days for complete epithelialization when compared with Neomycin, Phenytoin $1 \%$ and $10 \%$.

The results of days required for epithelialization of Phenytoin $1 \%$ and $10 \%$ of my study were in contrast to studies done by Hasamnis AA et al, Jarrahi $M$ et al, Qunaibi EA et al. ${ }^{1,2,6}$ Collagen is a major protein of extracellular matrix and is the component that ultimately contributes to wound strength. Breakdown of collagen fibres liberates free hydroxyproline and its peptide. Therefore measurement of hydroxyproline could be used as an index for determining collagen turnover. Phenytoin is found to enhance wound healing mainly by decreasing collagenase activity and promoting deposition of collagen. So, in our study hydroxyproline estimation of biopsied tissue was done on $6^{\text {th }}, 10^{\text {th }}$ and $14^{\text {th }}$ day after infliction of excision wounds. The hydroxyproline content of phenytoin $1 \%, 5 \%$ and $10 \%$ were significantly more in comparison to neomycin group with increase in the concentration of Phenytoin, there was significant increase in hydroxyproline content.

\section{CONCLUSION}

Phenytoin 5\% on topical application showed better wound healing in Excision wounds compared to Control and Neomycin. Phenytoin ointment can be used as cheap, effective, economical wound healing agent in chronic non healing and infective wounds. The effect of topical use of 
Phenytoin for promotion of wound healing seems promising but requires further Clinical trials.

Funding: No funding sources

Conflict of interest: None declared

Ethical approval: The study was approved by the Institutional Ethics Committee

\section{REFERENCES}

1. Hasamnis AA, Mohamthy BK, Muralikrishna, Patil S. Evaluation of wound healing effect of topical Phenytoin on excisional wound in albino rats. J Young Pharmacists. 2010;2:59-62.

2. Qunaibi E A, Disi A M, Taha M O. Phenytoin enhances collagenization in excision wounds and tensile strength in incision wounds. Pharmazie. 2009;64:584-6.

3. Reddy JS, Rao PR, Reddy MS. Wound healing effect of Heliotropium indicum Plumbago zeylanicum and Acalyoha indica in rats. $\mathrm{J}$ Ethnopharmacol. 2002;79(2):249-51.

4. Ashima Bhatia MD, Surya Prakash DVD. Topical Phenytoin for wound healing. Dermatology online J. 2004;10:5.

5. Naeini AT, Oryan A, Dehghani S. Effects of topical and parental application of Phenytoin on cutaneous wound healing in rabbits. $J$ Anim Vet Adv. 2008;7(12):1537-45.
6. Morteza Jarrahi, Abbas Ali Vafaei. Effect of topical Phenytoin cream on linear incisional wound healing in albino rats. Daru. 2004;12(4):156-8.

7. Morton JP, Malone MH. Evaluation of vulnerary activity by open wound procedure in rats. Arch Int Pharmacodyn. 1972;196:117-26.

8. Woessner JF, The determination of hydoxyproline in tissue and protein samples containing small proportions of this iminoacid. Arch biochem Biophys. 1961;93:440-.7

9. Kimball OP, Horan TN, The use of Dilantin in treatment of epilepsy. Ann Intern Med. 1939;13:78793.

10. Shaprio M. Accelaration of gingival wound healing in nonepileptic patients receiving diphenylhydantoin sodium. Exp Med Surg. 1958;16:41-53.

11. Modaghegh S, Salehian B, Tavassoli M, et al. Use of phenytoin in healing of war and non-war wounds. A pilot study of 25 cases. Int J Dermatol. 1989;28:34750 .

12. Muthukumaraswamy MG, Sivakumar G, Manoharan G. Topical Phenytoin in diabetic foot ulcers. Diabetes care. 1991;14:909-11.

13. Moy LS, Tan EM, Holness R, Uitto J. Phenytoin modulates connective tissue metabolism and cell proliferation in human skin fibroblast cultures Arch Dermatol. 1985;121:79-83

14. Pendse AK, Sharma A, Sodani A, Hada S. Topical phenytoin in wound healing. Int $J$ Dermatol. 1993;32:214-7.

Cite this article as: Usha NS, Sirisha G. Wound healing activity of topical phenytoin in excision wound model of Albino rats. Int J Basic Clin Pharmacol 2016;5:2683-7. 